\title{
Real-Time Evolution of Zika Virus Disease Outbreak, Roatán, Honduras
}

\author{
Trevor Brooks, Arup Roy-Burman, \\ Cascade Tuholske, Michael P. Busch, \\ Sonia Bakkour, Mars Stone, Jeffrey M. Linnen, \\ Kui Gao, Jayleen Coleman, Evan M. Bloch
}

A Zika virus disease outbreak occurred in Roatán, Honduras, during September 2015-July 2016. Blood samples and clinical information were obtained from 183 patients given a clinical diagnosis of suspected dengue virus infection. A total of 79 patients were positive for Zika virus, 13 for chikungunya virus, and 6 for dengue virus.

Z ika virus is a mosquitoborne flavivirus that is clinically nonspecific and associated with severe congenital injury (1-5). Zika virus is closely related to dengue virus (DENV), which is endemic to Roatán, the largest Honduran Bay island (population $\approx 46,000$ persons), located 50 $\mathrm{km}$ north of the Honduras mainland (6). However, most cases of DENV infection are diagnosed clinically because of limited capacity for laboratory confirmation.

We initiated a pilot study in 2015 to correlate clinical (signs and symptoms) and laboratory diagnostic findings for cases of presumptive dengue. As of September 2015, Zika virus had not been identified in Roatán. We report emergence of Zika virus on Roatán.

\section{The Study}

We conducted a cross-sectional survey of patients who came to Public Hospital Roatán during September 2015July 2016 and were given a clinical diagnosis of suspected dengue fever. This hospital, the only public hospital in Roatán, has 58 inpatient beds. Approximately $90 \%$ of dengue cases on Roatán are diagnosed at this hospital; most case-patients came to the emergency department, which had 18,578 visits in 2015 (Public Hospital Roatán Internal Statistics, unpub. data).

Author affiliations: University of California School of Medicine, San Francisco, California, USA (T. Brooks, A. Roy-Burman, M.P. Busch); University of California, Santa Barbara, California, USA (C. Tuholske); Blood Systems Research Institute, San Francisco (M.P. Busch, S. Bakkour, M. Stone, E.M. Bloch); Hologic Inc., San Diego, California, USA (J.M. Linnen, K. Gao); Public Hospital Roatán, Coxen Hole, Honduras (J. Coleman); Johns Hopkins School of Medicine, Baltimore, Maryland, USA (E.M. Bloch)

DOI: https://doi.org/10.3201/eid2308.161944
We used a convenience sampling approach. All patients $>2$ years of age given a diagnosis of clinically suspected DENV infection at the hospital during the enrollment period were eligible. Suspected DENV infection was diagnosed by using criteria of the Honduran Ministry of Health, which are fever plus 2 of the following: nausea/vomiting, rash, headache/retroorbital pain, myalgias/ arthralgias, petechiae/positive tourniquet test result, leukopenia, and bleeding.

Patients were enrolled after we obtained informed consent; minors were enrolled only after we obtained parental permission. Ethical approval was granted by institutional review boards of the University of California, San Francisco, and Universidad Nacional Autónoma de Honduras. Enrollment of participants and blood collection were restricted to workday hours (8:00 AM-4:00 PM) Monday through Friday. Patients underwent a phlebotomy and completed a clinical questionnaire, administered verbally in English or Spanish that addressed demographics, migration history, employment, medical history, and symptoms and signs of arbovirus infection.

Samples of whole blood (5-9 $\mathrm{mL})$ were collected in EDTA-treated vacutainers (BD Diagnostics, Franklin Lakes, NJ, USA) within $1 \mathrm{~h}$ of diagnosis. Samples were centrifuged $(35,000 \mathrm{rpm})$, which yielded sufficient plasma to prepare 5 equal aliquots (minimum $0.5 \mathrm{~mL} /$ aliquot). Aliquots were labeled with patient identification numbers and stored frozen at $-30^{\circ} \mathrm{C}$ pending testing.

In July 2016, samples were shipped on dry ice to Blood Systems Research Institute (San Francisco, CA, USA) where initial testing was performed by using the Trioplex Assay (Centers for Disease Control and Prevention, Atlanta, GA, USA) for detection of DENV, chikungunya virus (CHIKV), and Zika virus RNA. RNA was extracted from $140 \mu \mathrm{L}$ of plasma and eluted in $60 \mu \mathrm{L}$ of buffer (QIAamp Viral RNA Mini Kit; QIAGEN, Valencia, CA, USA).

Multiplex real-time reverse transcription PCR (RTPCR) was performed using the SuperScript III Platinum One-Step qRT-PCR Kit (ThermoFisher Scientific, Pittsburgh, PA, USA) with DENV, CHIKV, and Zika virus primers and probes developed at the Centers for Disease Control and Prevention. Each duplicate reaction contained $10 \mu \mathrm{L}$ of sample RNA in a reaction volume of $25 \mu \mathrm{L}$. Samples were tested in a 96-well format in a real-time instrument (LightCycler 480 System; Roche, Basel, Switzerland). Results were considered positive if the cycle threshold was $<38$. 
A more sensitive Zika virus-only test based on transcription-mediated amplification (Aptima Zika Virus Assay; Hologic Inc., San Diego, CA, USA), which processed $0.5-\mathrm{mL}$ plasma into each amplification reaction, was performed in parallel for all samples to confirm Zika virus infections detected by the Trioplex Assay and detect low levels of Zika virus RNA (7). The Aptima Assay was used for further analysis.

At conclusion of study enrollment, addresses of participants were mapped by using a hand-held eTrex 20 (Garmin, Lenexa, KS, USA), which generated global positioning system coordinates for their homes. The survey, laboratory test data, and global positioning system coordinates were uploaded into ArcGIS version 10.3.1 software (Esri, Inc., Redlands, CA, USA). All potential predictors of Zika virus infection were analyzed by using univariate logistic regression models in Stata version 13 (StataCorp LLC, College Station, TX, USA). Characteristics that were significant $(\mathrm{p}=0.10)$ by univariate analysis were entered into a multivariable logistic regression model.

A total of 183 patients participated and provided blood samples (Table 1). Most (60\%) patients were women. Mean age was 26 (interquartile range 19-37 years). Mean time to seeking treatment after onset of signs or symptoms was 3.2 days. The most commonly reported signs or symptoms were headache $(90 \%)$, arthralgia $(89 \%)$, myalgia $(87 \%)$, retroorbital pain $(71 \%)$, and rash (55\%). Most patients lived in homes that had a nondirt floor $(93 \%)$, running water $(81 \%)$, and electricity $(90 \%)$. Only $25 \%$ reported having mosquito nets over their beds. Six (3\%) of 183 patients were positive for DENV RNA, and 13 (75\%) were positive for CHIKV RNA. In contrast, Zika virus RNA was detectable in $66(36 \%)$ of 183 patients by the Trioplex assay and in $79(43 \%)$ of 183 patients by the Aptima assay.

The enrollment rate was low through the first part of the study, when $\leq 3$ case-patients/wk were enrolled (Figure 1). In the first week of February 2016, eight case-patients were enrolled, followed by 26 case-patients the following week. The first case of laboratory-confirmed Zika virus infection on Roatán occurred on January 27, 2016; Zika virus infection peaked (16 cases) during February 8-14. Timing of accrual of positive case-patients matched expected seasonality of arbovirus infection. Cases decreased steadily through the remainder of the sample collection period.

The Zika virus outbreak was focused in the major population centers in Coxen Hole, Los Fuertes, and French Harbor (Figure 2). Except for West Bay and West End, cases were widely distributed on the island. West Bay and West End are major tourist centers on Roatán; absence of cases might be ascribed to tourists and expatriates who were unlikely to seek medical attention at Public Hospital Roatán.

\begin{tabular}{|c|c|c|c|}
\hline Characteristic & Total, $n=183$ & $\begin{array}{l}\text { Zika virus infection, } \\
\qquad \mathrm{n}=79\end{array}$ & $\begin{array}{c}\text { No Zika virus infection, } \\
n=104\end{array}$ \\
\hline Age, $y$ & $26(19-37)$ & $27(21-38)$ & $24(17-35)$ \\
\hline \multicolumn{4}{|l|}{ Sex } \\
\hline M & 73 (39.9) & $28(35.4)$ & $45(43.3)$ \\
\hline $\mathrm{F}$ & $110(60.1)$ & $51(64.6)$ & $59(56.7)$ \\
\hline \multicolumn{4}{|l|}{ Living conditions } \\
\hline Dirt floor & $12(6.6)$ & $4(5.1)$ & $8(7.7)$ \\
\hline Running water & 149 (81.4) & $71(89.9)$ & $78(75.0)$ \\
\hline Electricity & $165(90.2)$ & 75 (94.9) & $90(86.5)$ \\
\hline Mosquito nets over beds & $46(25.1)$ & $22(27.8)$ & $24(23.1)$ \\
\hline Rooms & $2(1-2)$ & $2(1-3)$ & $2(1-2)$ \\
\hline Persons in household & $4(3-5.5)$ & $4(3-5)$ & $4(3-6)$ \\
\hline \multicolumn{4}{|l|}{ Sign or symptoms } \\
\hline Headache & $165(90.2)$ & 75 (94.9) & $90(86.5)$ \\
\hline Muscle aches & $159(86.9)$ & $67(84.8)$ & $92(88.5)$ \\
\hline Joint ache & $162(88.5)$ & $71(89.9)$ & $91(87.5)$ \\
\hline Eye pain & $131(71.6)$ & $61(77.2)$ & $70(67.3)$ \\
\hline Rash & $102(55.7)$ & $73(92.4)$ & $29(27.9)$ \\
\hline Bleeding & $1(0.5)$ & 0 & $1(1.0)$ \\
\hline Vomiting & $49(26.8)$ & $11(13.9)$ & $38(36.5)$ \\
\hline Petechiae & $5(2.7)$ & $2(2.5)$ & $3(2.9)$ \\
\hline Epistaxis & $1(0.5)$ & 0 & $1(1.0)$ \\
\hline Gingivitis & $3(1.6)$ & $1(1.3)$ & $2(1.9)$ \\
\hline Other & $123(67.2)$ & $53(67.1)$ & $70(67.3)$ \\
\hline Body temperature, ${ }^{\circ} \mathrm{C}$, mean $(\mathrm{SD})$ & $37.8(1.1)$ & $37.3(0.9)$ & $38.1(1.1)$ \\
\hline Days between symptom onset and seeking treatment & $3(1-4)$ & $3(1-4.5)$ & $2(2-4)$ \\
\hline \multicolumn{4}{|l|}{ History of infectious diseases } \\
\hline Dengue & $45(24.6)$ & $21(26.6)$ & $24(23.1)$ \\
\hline Malaria & $33(18.0)$ & $18(22.8)$ & $15(14.4)$ \\
\hline Chikungunya & $61(33.3)$ & $28(35.4)$ & $33(31.7)$ \\
\hline
\end{tabular}

*Values are median (IQR) or no. (\%) unless indicated otherwise. IQR, interquartile range. 


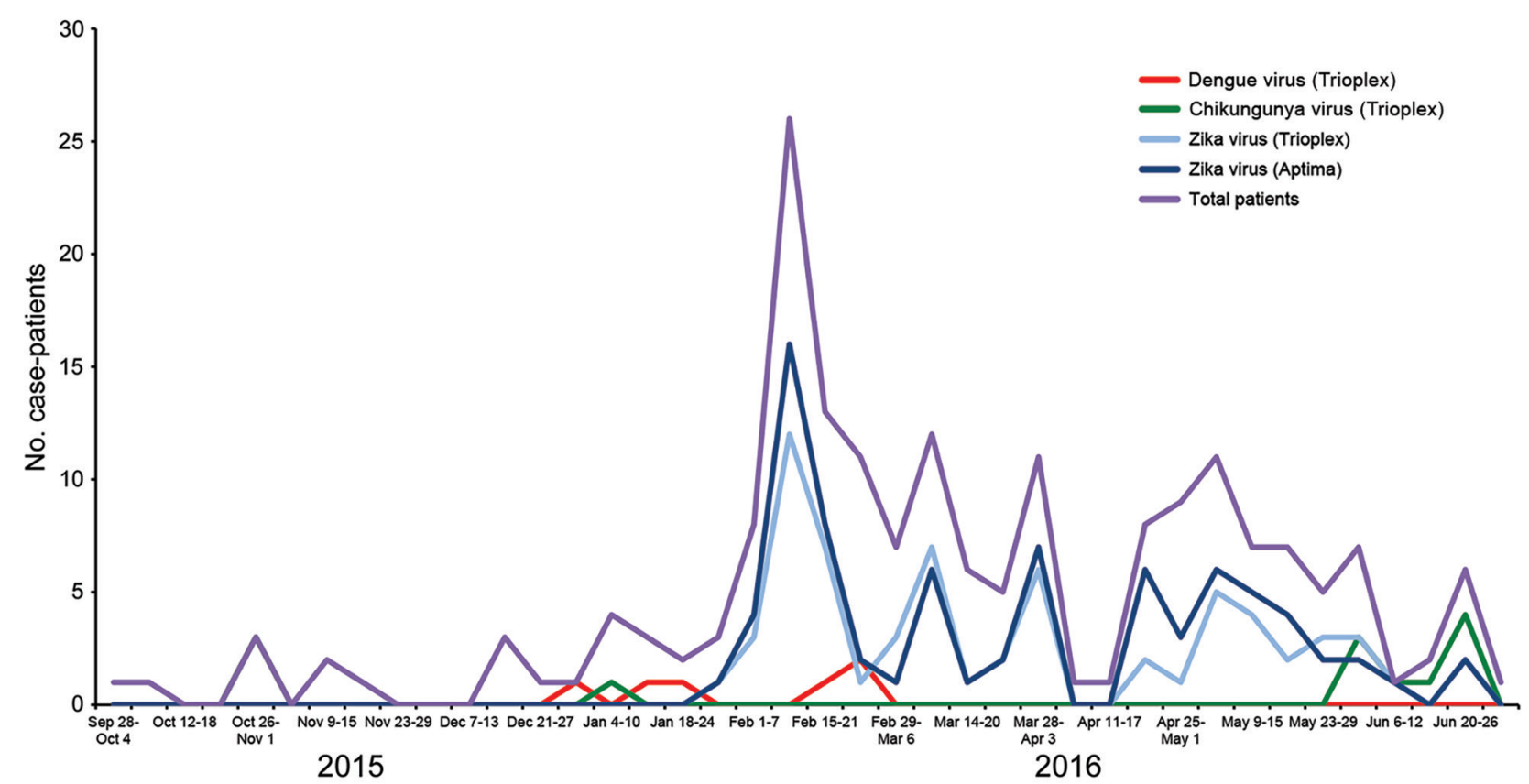

Figure 1. Weekly case occurrence of Zika virus, dengue virus, and chikungunya virus infections, by testing type, Roatán, Honduras, September 2015-July 2016. Aptima, Aptima Zika Virus Assay (Hologic Inc., San Diego, CA, USA); Trioplex, Trioplex Assay (Centers for Disease Control and Prevention, Atlanta, GA, USA).

Multivariable analysis showed that rash (odds ratio [OR] 30.6, 95\% CI 10.8-86.9) and headache (OR 11.2, $95 \%$ CI 2.7-46.7) were independently associated with Zika virus infection. Fever (OR 0.44, 95\% CI 0.26-0.74) and vomiting (OR $0.25,95 \%$ CI $0.08-0.73$ ) were associated with a decreased risk for Zika virus infection (Table 2).

This study had limitations. Our exclusive enrollment of patients who came to Public Hospital Roatán excluded patients who came to other healthcare facilities or outside daytime working hours who were not sufficiently symptomatic to seek care. Alternative body fluids (e.g., saliva, urine, whole blood) were not available for testing, and serologic testing for Zika virus was not performed because of cost constraints and cross-reactivity between Zika virus and DENV antibodies. We did not perform confirmatory testing of CHIKV- and
DENV-positive samples. This study could be biased for detecting Zika virus and not DENV/CHIKV because of use of a more sensitive assay.

\section{Conclusions}

We demonstrated the evolution of the Zika virus disease outbreak in Roatán, Honduras, in early 2016. Findings highlight challenges in case ascertainment based only on clinical diagnosis. In the absence of laboratory confirmation, clinical diagnosis has low specificity because of overlap of signs and symptoms between infections with Zika virus, DENV, CHIKV, and a host of other regionally endemic infections. Enrollment was contingent upon a suspected diagnosis of dengue. However, DENV was detected in $<5 \%$ of case-patients, whereas $43 \%$ of case-patients had acute Zika virus infections.

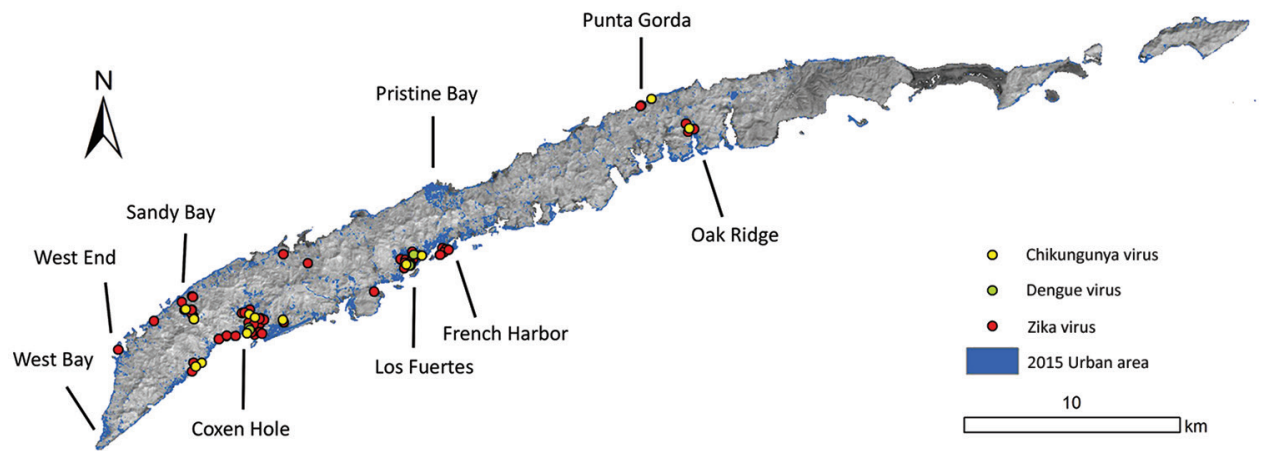

Figure 2. Spatial distribution of confirmed cases of infection with Zika virus, dengue virus, and chikungunya virus, Roatán, Honduras, September 2015July 2016. 
Table 2. Logistic regression analysis of predictors for Zika virus infection, Roatán, Honduras, September 2015-July 2016

\begin{tabular}{|c|c|c|c|c|}
\hline \multirow[b]{2}{*}{ Characteristic } & \multicolumn{2}{|c|}{ Univariate logistic regression } & \multicolumn{2}{|c|}{ Multivariable logistic regression } \\
\hline & Odds ratio $(95 \% \mathrm{Cl})$ & $p$ value & Odds ratio $(95 \% \mathrm{Cl})$ & $p$ value \\
\hline \multicolumn{5}{|l|}{ Household } \\
\hline Running water & $2.96(1.26-6.96)$ & 0.01 & $2.93(0.78-11.1)$ & 0.11 \\
\hline Electricity & $2.92(0.92-9.24)$ & 0.07 & $2.36(0.39-14.3)$ & 0.35 \\
\hline \multicolumn{5}{|l|}{ Sign or symptom } \\
\hline Headache & $2.92(0.92-9.24)$ & 0.07 & $11.20(2.70-46.7)$ & 0.001 \\
\hline Rash & $31.5(12.3-80.2)$ & $<0.0001$ & $30.6(10.8-86.9)$ & $<0.0001$ \\
\hline Vomiting & $0.28(0.13-0.60)$ & 0.001 & $0.25(0.08-0.73)$ & 0.01 \\
\hline Fever & $0.38(0.25-0.57)$ & $<0.0001$ & $0.44(0.26-0.74)$ & 0.002 \\
\hline
\end{tabular}

After a rapid peak in early February 2016, there was a slow decrease in reported cases through July 2016, when enrollment concluded. Access to laboratory testing remains a barrier to surveillance and clinical management in lowresource countries where Zika virus disease outbreaks are predominantly focused, but laboratory infrastructure is lacking (2).

\section{Acknowledgments}

We thank Martha Medina and staff at the Public Hospital Roatán for support, Omar Brito and Fermin Lopez for approving and supporting the study, Liz Vinelli for kindly facilitating logistical oversight, Eva Harris for providing mentorship and input on the initial study, and the US Geological Suvey for providing Landsat imagery.

This study was supported by a Doris Duke International Clinical Research Fellowship, the Broom Center for Demography, and the National Center for Advancing Translational Sciences, National Institutes of Health (grant UL1 TR000004).

Mr. Brooks is a fourth-year medical student at the University of California School of Medicine, San Francisco, CA. His research interests are global health and infectious diseases.

\section{References}

1. World Health Organization. Zika situation report. September, 29, 2016 [cited 2017 Apr 20]. http://www.who.int/emergencies/ zika-virus/situation-report/29-september-2016/en/

2. Plourde AR, Bloch EM. A literature review of Zika virus. Emerg Infect Dis. 2016;22:1185-92. http://dx.doi.org/10.3201/eid2207.151990

3. Hayes EB. Zika virus outside Africa. Emerg Infect Dis. 2009;15:134750. PubMed http://dx.doi.org/10.3201/eid1509.090442

4. Duffy MR, Chen TH, Hancock WT, Powers AM, Kool JL, Lanciotti RS, et al. Zika virus outbreak on Yap Island, Federated States of Micronesia. N Engl J Med. 2009;360:2536-43. http://dx.doi.org/10.1056/NEJMoa0805715

5. Hennessey M, Fischer M, Staples JE. Zika virus spreads to new areas-region of the Americas, May 2015-January 2016. MMWR Morb Mortal Wkly Rep. 2016;65:55-8. http://dx.doi.org/10.15585/ mmwr.mm6503e1

6. National Statistics Institute. Census of population and housing, 2013. October 22, 2015, Tegucigalpa [in Spanish] [cited 2017 Apr 20]. http://www.ine.gob.hn/index.php/component/content/article?id=102

7. Stone M, Lanteri MC, Bakkour S, Deng X, Galel SA, Linnen JM, et al. Relative analytical sensitivity of donor nucleic acid amplification technology screening and diagnostic real-time polymerase chain reaction assays for detection of Zika virus RNA. Transfusion. 2017;57:734-47. http://dx.doi.org/10.1111/trf.14031

Address for correspondence: Trevor Brooks, University of California School of Medicine, 505 Parnassus Ave, San Francisco, CA 94143-0410, USA; email: trevor.brooks@ucsf.edu

\section{EID Adds Advanced Search Features for Articles}

Emerging Infectious Diseases now has an advanced search feature that makes it easier to find articles by using keywords, names of authors, and specified date ranges. You can sort and refine search results by manuscript number, volume or issue number, or article type. A quick start guide and expandable help section show you how to optimize your searches.

\section{https://wwwnc.cdc.gov/eid/AdvancedSearch}

EID's new mapping feature allows you to search for articles from specific countries by using a map or table to locate countries. You can refine search results by article type, volume and issue, and date, and bookmark your search results.

\section{https://wwwnc.cdc.gov/eid/ArticleMap}

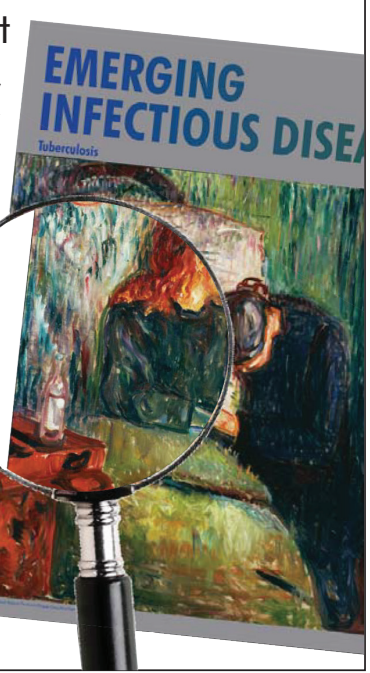

